\title{
Regional Business Cycle Phases in Spain*
}

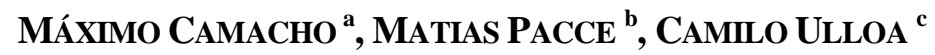 \\ a Universidad de Murcia, Facultad de Economía y Empresa, Campus de Espinardo, s/n, 30100 \\ Murcia, España.E-mail: mcamacho@um.es \\ b Banco de España, División de Política Monetaria y Área del Euro, c/ Alcalá, 48, 28014 Madrid, \\ España.E-mail: matias.pacce@bde.es \\ c BBVA Research, Unidad de España y Portugal, Ciudad BBVA - C/ Azul, 4 - Edificio La Vela, 28050 \\ Madrid,España.E-mail: camiloandres.ulloa@bbva.com
}

\begin{abstract}
We characterize regional business cycles for Spain using monthly Social Security affiliations. Based on a set of Markov-switching models, we find substantial synchronization of regional business cycles, which has increased since the Great Recession. We also find evidence of a regional leading and lagging performance that repeats itself across the different recessions. Typically, earlier signals of national recessions appear in the Islands and Valencia, and are propagated from the periphery to the center. Moreover, north-western regions tend to start the regional recoveries with a significant lag.
\end{abstract}

Keywords: Regional Business Cycles, Cyclical Synchronization, Time Series.

\section{Ciclos económicos regionales en España}

\section{RESUMEN}

Se caracterizan los ciclos económicos regionales en España utilizando series mensuales de afiliados a la Seguridad Social. Con base en un conjunto de modelos de cadenas de Markov, se encuentra evidencia substancial de sincronización entre los ciclos económicos de las distintas regiones, la cual se ha incrementado desde la Gran Recesión. También se encuentra evidencia de patrones de retraso o adelantamiento en la transmisión de los ciclos, los cuales se repiten a largo de las distintas recesiones. En general, las primeras señales de una recesión regional comienzan a verse en las Islas y en la Comunidad Valenciana, y se propagan desde la periferia hacia el centro. Asimismo, las regiones del noroeste tardan más tiempo en comenzar a recuperarse.

Palabras clave: Ciclos económicos regionales, Sincronización de los ciclos económicos, series temporales.

Clasificación JEL: E32, C22, E27

\footnotetext{
${ }^{*}$ We are grateful to Miguel Cardoso for their comments, which have greatly improved the quality of this paper. M. Camacho acknowledges support from projects ECO2016-76178-P and 19884/GERM/15 (Groups of Excellence, Fundación Séneca, and Science and Technology Agency). We take responsibility for all remaining errors. The views expressed in this paper are my own and do not necessarily reflect the views of the Banco de España or the European System of Central Banks (ESCB).
}

Artículo recibido en febrero de 2018 y aceptado en mayo de 2018

Artículo disponible en versión electrónica en la página www.revista-eea.net, ref. ə-36301

ISSN 1697-5731 (online) - ISSN 1133-3197 (print) 


\section{INTRODUCTION}

A country business cycle could be characterized as a series of aggregate recession and expansion phases which, nevertheless, might not match all of the country's regional cycles perfectly. Although regional economic fluctuations may propagate across the nation, differences could emerge, not only in terms of average growth rates of contractions and expansions, but also their dating and persistence. Disentangling regional business cycles' stylized facts, as well as their propagation dynamics, could be useful for policy-makers in order to implement the appropriate countercyclical measures at the right time in those regions where they may be most necessary and effective. In this context, a renewed interest in understanding business cycles at a disaggregated level has emerged since the 2008 global financial crisis broke out. While not claiming to be exhaustive, some relevant examples are Ozyurt and Dees (2015), Bandrés et al. (2017), and Leiva-Leon et al. (2017).

When studying real business cycles, labour market dynamics have been of central importance (see, among others, Kydland and Prescott, 1982; Blanchard and Quah, 1989; and Galí, 1999). This is particularly relevant in Spain, a country with a high structural unemployment rate and a significant pro-cyclical employment performance (see Andres and Domenech, 2015; Dixon et al., 2016). Based on the assumption that employment is a good proxy for economic activity in Spain, in this paper we characterize the regional business cycle dynamics of the 17 Spanish autonomous communities (which matches NUTS-2 in the EUROSTAT nomenclature) while studying their synchronization and specificities. Our work is thus closely related to that of Cancelo (2004) and Gadea et al. (2012), who used Bry-Boschan dating algorithms on regional data to examine Spanish regional business cycles. The first of these used by the authors were based on regional quarterly employment data from the Labour Force Survey (LFS) for the 1777-2003 period and the second on the monthly industrial production data from 1991.10 to $2010.12{ }^{1}$

We make our contribution to the above mentioned literature in several ways. First, as the measure of the regional economic activity, we rely on Social Security affiliation, which is a monthly employment indicator, rather than on the quarterly employment data from the Labour Force Survey (LFS) used by Cancelo (2004). By using the closer timing of the monthly series, we hope to find earlier signals of turning points than those obtained using the quarterly data. Second, we follow Owyang, Piger, and Wall (2005) to draw inferences from the regional business cycles, based on Hamilton (1989), and propose that growth rates of the regional affiliation are characterized by a recurrent sequence

${ }^{1}$ Basile and Girardi (2018) proposed an excellent review of the uncertainty/economic activity nexus. 
of shifts between two fixed equilibria of high and low growth means, where regime shifts are governed by an unobserved first-order Markov chain. This shows a complementary approach to the non-parametric Bry-Boschan data algorithm employed by Gadea et al. (2012) to regional industrial production indices. Last but not least, our sample includes data from 1983.01 to 2017.05, which allows us to examine the regional business cycles in Spain for the Great Recession period.

Three main results can be highlighted from the empirical analysis set out in this paper. First, we find significant evidence of a two-regime business cycle for each of the Spanish regions. Second, we document the existence of three national recession periods, viz 1983-1985, 1991-1994, and 2008-2014. Overall, most of the regional business cycle experiences are similar to those of the nation as a whole. Third, although synchronization of the regional business cycles has increased, we find substantial heterogeneity across regional recessions. In several recessions, different parts of the country seem to have manifested the first signs of the downturns and subsequent recoveries.

Using this model, we detect several thought-provoking recurrent business cycle patterns on a regional level in Spain. First, the Canary Islands, Valencia and, to a lesser extent, the Balearic Islands typically lead the national peaks. Then, these regions seem to be good candidates to serve as a barometer for coming recessions. Second, the propagation of the regional recessions to the national level seems to be inwards, from the periphery to the center. Third, north-western regions are the last to show signs of regional recoveries after the national troughs.

The remainder of this paper is organized as follows. Section 2 describes the data and develops a preliminary data analysis. Section 3 states the framework used to compute regional expansion and recession phases. Sections 4 and 5 describe the key results regarding the regional employment cycle pattern. Section 6 concludes.

\section{PRELIMINARY DATA ANALYSIS}

Two things are required to study co-movement on a regional level over the business cycle: a regional measure of economic activity and a precise definition of regional business cycles. Although regional GDP would be the most convenient measure of regional economic activity, this is not available, neither at a high frequency nor for a large sample on a regional level. Then, we were precluded from using the regional series of GDP to examine the regional business cycles.

In this paper, the economic activity in a given region is measured by the annual growth rates of Social Security affiliation. The data come from the Ministry of Employment and Social Security, which reports the monthly readings 
for the 17 Spanish Autonomous Communities that fall within NUTS-2 in the EUROSTAT nomenclature. ${ }^{2}$ Country level data is also included in the sample to facilitate comparisons. Our sample period is 1983.01-2017.05, which, according to the Spanish Business Cycle Dating Committee, covers three national recessions. ${ }^{3}$ To obtain seasonally adjusted versions of the series, the additive outliers and level shifts were automatically corrected by using the TRAMOSEATS statistical software developed by the Bank of Spain.

Table 1

Correlations of regional GDP and selected indicators

\begin{tabular}{lcccc}
\hline $\begin{array}{l}\text { Autonomous } \\
\text { Communities }\end{array}$ & $\begin{array}{c}\text { Social Security } \\
\text { Affiliation }\end{array}$ & Employment LFS & Employment RNA & $\begin{array}{c}\text { Industrial } \\
\text { Production Index }\end{array}$ \\
\hline Andalusia & 0.97 & 0.95 & 0.97 & 0.86 \\
Aragon & 0.91 & 0.74 & 0.92 & 0.69 \\
Asturias & 0.97 & 0.88 & 0.95 & 0.69 \\
Balearic Islands & 0.91 & 0.76 & 0.92 & 0.84 \\
Canary Islands & 0.88 & 0.86 & 0.94 & 0.77 \\
Cantabria & 0.96 & 0.88 & 0.91 & 0.63 \\
C-Mancha & 0.93 & 0.92 & 0.94 & 0.61 \\
C- Leon & 0.96 & 0.92 & 0.96 & 0.65 \\
Catalonia & 0.96 & 0.90 & 0.97 & 0.66 \\
Valencia & 0.95 & 0.96 & 0.96 & 0.75 \\
Extremadura & 0.90 & 0.83 & 0.94 & 0.61 \\
Galicia & 0.97 & 0.89 & 0.98 & 0.75 \\
Madrid & 0.97 & 0.88 & 0.96 & 0.90 \\
Murcia & 0.92 & 0.84 & 0.92 & 0.78 \\
Navarre & 0.96 & 0.89 & 0.96 & 0.76 \\
Basque C. & 0.94 & 0.87 & 0.95 & 0.86 \\
Rioja & 0.94 & 0.79 & 0.91 & 0.74 \\
\hline
\end{tabular}

Notes. The table shows the correlations of regional GDP and selected activity and employment indicators. The second column refers to Social Security affiliation (Ministry of Employment and Social Security). The third and fourth columns refer to employment and come from the National Statistical Institute in the Labour Force Survey from and the Regional National Accounts, respectively. The last column refers to the Industrial Production Index.

Source: Own elaboration base on MEySS and INE data.

The main advantages of using the Social Security Affiliation data as an indicator of regional economic activity in Spain are its monthly frequency and its early publication dates, which occurs at the second working day of the month following that to which the data refers. Other employment indicators such as those produced by the National Statistical Institute (NSI) in the Labour Force Survey (LFS) and the Regional National Accounts (RNA) have a quarterly and

\footnotetext{
${ }^{2}$ These regions are Andalusia, Aragon, Asturias, Balearic Islands, the Canary Islands, Cantabria, Castilla-Leon, Castilla-La Mancha, Catalonia, the Valencian Community, Extremadura, Galicia, the Community of Madrid, Murcia, Navarre, the Basque Country and La Rioja.

${ }^{3}$ The three Spanish national recessions identified by the Committee during this period are 1992.11993.3, 2008.2-2009.4 and 2010.4-2013.2.
} 
annual frequency, respectively, and are published with a greater delay with respect to the period to which they refer. Specifically, the LFS is published at the end of the first month for the quarter immediately following the one to which the statistics relate, while the RNA first estimate is published at the end of the first quarter of the year following the one to which the data relate.

Likewise, social security affiliation is published before other monthly shortterm indicators, frequently used as a proxy for the activity, such as Industrial Production Index. This index is published four or five weeks following the reference month of the data. By using the closer timing of the Social Security affiliation monthly series, we hope to find earlier signals of business cycle changes.

One additional advantage of using affiliation to Social Security as an indicator of activity for the Spanish economy is its high correlation with regional GDP. As Table 1 shows, the correlation between its growth rates and the 2010 base officially available annual regional GDP growth is high and, in most cases, higher to that observed for the employment data provided by the Labour Force Survey and the Regional National Accounts, for Industrial Production.

\section{MARKOV-SWITCHING MODELS AND THE BUSINESS CYCLE}

To identify business cycle turning points, we apply the Markov regimeswitching model used by Hamilton (1989) for each region, which has the advantage with respect to the data-driven algorithm proposed by Bryand and Boschan (1971) of not requiring that recessions be absolute declines in Social Security affiliation. It is thus quite possible that, in a given region, Social Security affiliation can increase during recession, though at lower rates than in upswings.

Accordingly, the definition of business cycles followed in this paper relies on the recognised empirical fact that although series on affiliation levels present trends, they are not monotonic curves, but rather exhibit sequences of upturns and downturns. During periods known as recessions, the values of annual growth rates in affiliation are usually lower (and sometimes negative) than during periods of expansion.

Following Hamilton (1989), we assume that the switching mechanism of the $k$-th region in the annual growth rates of affiliates in month $t, y_{k t}$, is controlled by an unobservable state variable, $s_{k t}$. Owyang et al. (2005) specify a simple switching model that captures this non-linear dynamic:

$$
y_{k t}=\mu_{k s_{k t}}+\varepsilon_{k t} \text {, }
$$

where the nonlinear behaviour of the time series is governed by $\mu_{s_{t}}$, which is 
allowed to change within each of the two distinct regimes $s_{k t}=0$ and $s_{k t}=1 .^{4}$ Assuming $\mu_{k 0}>\mu_{k 1}$ identifies the regime $s_{k t}=0$ as the high-growth regime and the regime $s_{k t}=1$ as the low-growth regime. Deviations from this switching mean growth rates are generated by $\varepsilon_{k t}$, which is an i.i.d. Gaussian stochastic disturbance with a mean of zero and variance $\sigma_{\varepsilon_{k}}^{2}$.

Although an actual regional business cycle regime is not observable, the transitions between states can be modelled as a hidden first-order Markov process. This implies that the transition probabilities are independent of the information set at $t-1, \chi_{k t-1}$, and of the regimes prior to $t-1$. Accordingly, the probability of remaining in one particular state is

$$
p\left(s_{k t}=i / s_{k t-1}=j, s_{k t-2}=h, \ldots, \chi_{t-1}\right)=p\left(s_{k t}=i / s_{k t-1}=j\right)=p_{k i j},
$$

where $\chi_{k t}=y_{k 1}, \ldots, y_{k t}$. Note here that the models are estimated separately, which implies an ex ante agnostic approach regarding the dependency of business cycle phases across regions. ${ }^{5}$

\section{REGIONAL BUSINESS CYCLES}

\subsection{Regional characteristics}

A few summary statistics describing the estimated growth rates within each of the two phases appear in Table 2. Specifically, the table reports the maximum likelihood estimates of the within-regime means along with their 95\% coverage intervals. Although there is a variety of regional business cycle characteristics, the figures show that the estimated mean is positive when $s_{t}=0$, while it is negative when $s_{t}=1$, for all the regions. Therefore, the first regime can be associated with periods of expansion or periods of positive growth in affiliation levels, while the second regime refers to recessions or periods in which affiliation drops off. Table 2 also shows that the difference between the within-regime means is large and statistically significant, indicating that the regimes are wellseparated.

According to the figures reported in Table 2, we find that there are large crossregional differences. Low-phase growth rates range from $-1.14 \%$ to $-3.46 \%$, while high-phase rates span from $1.65 \%$ to $4.8 \%$. The destruction of employment in recession is particularly high in Castilla-La Mancha and Asturias, where

\footnotetext{
${ }^{4}$ The Federal Reserve Bank of St. Louis uses this model (Chauvet and Hamilton, 2006) to compute the US GDP-based recession indicator. Camacho and Perez-Quiros (2007) show that this model captures the U.S. business cycle dynamics with a great degree of precision.

${ }^{5}$ Inter-regional conditional transition probabilities are left for further research.
} 
employment contracts by $3.46 \%$ and $2.98 \%$, respectively. The latter, with an estimated growth rate of $1.65 \%$, presents the lowest job-creation capacity in expansionary phases. Employment in Asturias is therefore the most affected by business cycle fluctuations. By way of contrast, Balearic Islands employment tended to have had the highest growth rates across both phases. This region, together with the Canary Islands, which also shows high employment growth rates during expansionary phases, shows tourism to be a key sector in boosting employment in upturns.

Table 2

Maximum Likelihood Estimates

\begin{tabular}{lcccc}
\hline $\begin{array}{l}\text { Autonomous } \\
\text { Communities }\end{array}$ & Recession & Coverage Interval & Expansion & Coverage Interval \\
\hline Spain & -1.784 & $(-2.067,-1.502)$ & 3.429 & $(3.233,3.624)$ \\
\hline Andalusia & -2.724 & $(-3.062,-2.386)$ & 3.626 & $(3.440,3.812)$ \\
Aragon & -2.130 & $(-2.413,-1.847)$ & 2.888 & $(2.710,3.067)$ \\
Asturias & -2.987 & $(-3.292,-2.681)$ & 1.652 & $(1.479,1.825)$ \\
Balearic Islands & -1.148 & $(-1.487,-0.808)$ & 4.864 & $(4.585,5.143)$ \\
Canary Islands & -2.667 & $(-3.236,-2.099)$ & 4.425 & $(4.157,4.693)$ \\
Cantabria & -1.611 & $(-1.870,-1.351)$ & 3.178 & $(2.941,3.414)$ \\
C-Mancha & -3.465 & $(-3.939,-2.991)$ & 3.157 & $(2.917,3.396)$ \\
C - Leon & -1.811 & $(-2.027,-1.596)$ & 2.197 & $(2.043,2.351)$ \\
Catalonia & -2.248 & $(-2.556,-1.940)$ & 3.482 & $(3.274,3.689)$ \\
Valencia & -2.944 & $(-3.301,-2.586)$ & 3.797 & $(3.560,4.034)$ \\
Extremadura & -1.510 & $(-1.831,-1.189)$ & 2.382 & $(2.195,2.570)$ \\
Galicia & -1.654 & $(-1.893,-1.415)$ & 2.397 & $(2.222,2.571)$ \\
Madrid & -1.982 & $(-2.358,-1.606)$ & 3.430 & $(3.213,3.647)$ \\
Murcia & -2.144 & $(-2.566,-1.723)$ & 4.760 & $(4.492,5.028)$ \\
Navarre & -1.723 & $(-1.994,-1.452)$ & 3.239 & $(3.067,3.410)$ \\
Basque C. & -1.402 & $(-1.628,-1.176)$ & 2.419 & $(2.259,2.579)$ \\
Rioja & -2.540 & $(-2.861,-2.219)$ & 3.203 & $(2.999,3.406)$ \\
\hline
\end{tabular}

Notes. The table shows the maximum likelihood estimates; 95\% coverage intervals are shown in brackets.

Source: Own elaboration base on MEySS and INE data.

Furthermore, Mediterranean regions tend to amplify the business cycle in terms of employment. Employment contractions during recessions are severe in Andalusia, Murcia, Valencia and Catalonia. These regions, together with the Balearic Islands, are among those with the largest growth in affiliation levels during expansionary phases. In contrast, Madrid, Navarre and Cantabria show within-regime growth rates in affiliation that closely match those nationwide.

The corresponding estimates of business cycle persistence, $p_{i i}$, are given in Table 3. The table shows that each regime is highly persistent, with estimated probabilities of a regime being followed by the same regime above 0.9. Using the transition probabilities, one can also derive the expected number of months that a business cycle phase prevails as $\left(1-p_{i i}\right)^{-1}$. Conditional on being in state 0 , the 
expected duration of a typical national expansionary phase is a shade under 134 months. Likewise, conditional on being in the recession regime, the expected duration of a national recession is about 48 months.

Table 3

Business cycle persistence

\begin{tabular}{lcccc}
\hline \multicolumn{1}{c}{ Autonomous } & $\begin{array}{c}\text { Expansion } \\
\text { Probability of } \\
\text { Remaining }\end{array}$ & $\begin{array}{c}\text { Expected } \\
\text { Duration }\end{array}$ & $\begin{array}{c}\text { Probability of } \\
\text { Remaining }\end{array}$ & $\begin{array}{c}\text { Expected } \\
\text { Duration }\end{array}$ \\
\hline Spain & 0.993 & 133.702 & 0.979 & 47.601 \\
\hline Andalusia & 0.994 & 153.974 & 0.981 & 51.483 \\
Aragon & 0.989 & 94.119 & 0.977 & 42.878 \\
Asturias & 0.989 & 93.873 & 0.974 & 38.691 \\
Balearic Islands & 0.983 & 59.429 & 0.971 & 34.130 \\
Canary Islands & 0.991 & 111.821 & 0.973 & 36.461 \\
Cantabria & 0.983 & 60.353 & 0.980 & 48.867 \\
C-Mancha & 0.993 & 148.454 & 0.969 & 32.167 \\
C - Leon & 0.992 & 132.162 & 0.979 & 48.329 \\
Catalonia & 0.993 & 135.175 & 0.979 & 47.018 \\
Valencia & 0.989 & 92.425 & 0.970 & 33.407 \\
Extremadura & 0.986 & 71.111 & 0.966 & 29.807 \\
Galicia & 0.992 & 127.668 & 0.980 & 50.732 \\
Madrid & 0.990 & 96.792 & 0.974 & 39.128 \\
Murcia & 0.989 & 92.695 & 0.970 & 33.223 \\
Navarre & 0.993 & 137.820 & 0.976 & 41.731 \\
Basque C. & 0.992 & 131.928 & 0.979 & 47.619 \\
Rioja & 0.992 & 119.179 & 0.980 & 50.569 \\
\hline
\end{tabular}

Notes. The probabilities of remaining in expansion and recession of the $k$-th region are $p_{k 00}$ and $p_{k 11}$, respectively. The expected number of months that a business cycle phase prevails is computed as $\left(1-p_{k i i}\right)^{-1}$

Source: Own elaboration base on MEySS data.

However, the table shows that there are significant differences across regions. The longest expected expansion phases arise in Andalusia, Castilla-La Mancha and Navarre, while the Balearic Islands and Extremadura present the shortest. The expected duration of a recession is high in Andalusia, La Rioja and Galicia, while recession is expected to be short-lived in Extremadura, Castilla-La Mancha and Valencia. Even though for all the regions the expected duration is longer in expansionary phases than in recessions, the difference is particularly pronounced Castilla-La Mancha, Andalusia and Navarre. ${ }^{6}$ Conversely, the Balearic Islands and Extremadura exhibit the most similar duration of their regimes.

\footnotetext{
${ }^{6}$ The larger differences are explained by the lengthy expected duration of their expansionary phases.
} 


\subsection{Regional business cycles dynamics}

Figure A1 helps to chart the progress of the disaggregated business cycle phases by plotting the Social Security affiliation growth rates for each region, together with their full-sample smoothed probability of recession. ${ }^{7}$ The national recession probability is also plotted by way of a reference. The figure illustrates that it is easy to infer whether each region is in its recession or expansionary phase at any point in time because, with a few exceptions, the probability tends to shift sharply between values close to zero and one. ${ }^{8}$

Although the Spanish Business Cycle Dating Committee placed three recessions in Spain in 1992-1993, 2008-2009 and 2010-2013, the probability of negative growth in national affiliation indicates that the national employment recessions occur in 1983-1985, 1991-1994 and 2008-2014. ${ }^{9}$ Therefore, with the exception of the 1983-1985 downturn, the recessions based on national employment data fit in well with the Dating Committee dates. ${ }^{10}$

A more general picture of how regional business cycles relate to each other and with the national economy is provided by Figure 1 . The figure plots shaded areas that indicate when a region is estimated to be in recession over the sample period. Light colours indicate weaker evidence of recession, while the darker the shade, the stronger the statistical confidence that the indicated region was in recession at that time.

From Figures 1 and A1, two broad conclusions emerge. The first one is that, despite the unrestricted approach that we use to compute inferences on the regional business cycles, there appears to be a strong national component to most regional recessions. In spite of this finding, the second conclusion is that there is still a substantial heterogeneity across regional recessions, with differences across states that appear to be a matter of both timing (with some states entering a recession or recovering before others) and of the idiosyncrasy of certain regions that miss out on the 1983-1985 national recession, while others include extra regional recessions that are not shared by the country as a whole. These results are in line with Gadea et al. (2012), who also document that Spanish regional cycles are quite heterogeneous but display a certain degree of synchronization.

\footnotetext{
${ }^{7}$ The full-sample probabilities substantially smooth out a number of minor temporary blips in the filtered estimates, which is a clear advantage when analyzing a time series in a post-processing manner.

${ }^{8}$ The figure also plots the 95\% confidence bands, which are computed after Alvarez, Camacho and Ruiz (2018).

${ }^{9}$ Cancelo (2004) also finds the 1983-1985 recession. The 1991-1994 downturn and the Great Recession also appear in Gadea et al. (2012).

${ }^{10}$ Interestingly, the double-dip recession that the Dating Committee placed in 2008-2009 and 20102013 was recognised to be just a single recession that started in 2008 and ended in 2014.
} 
Figure 1

Regional versus national business cycle phases.

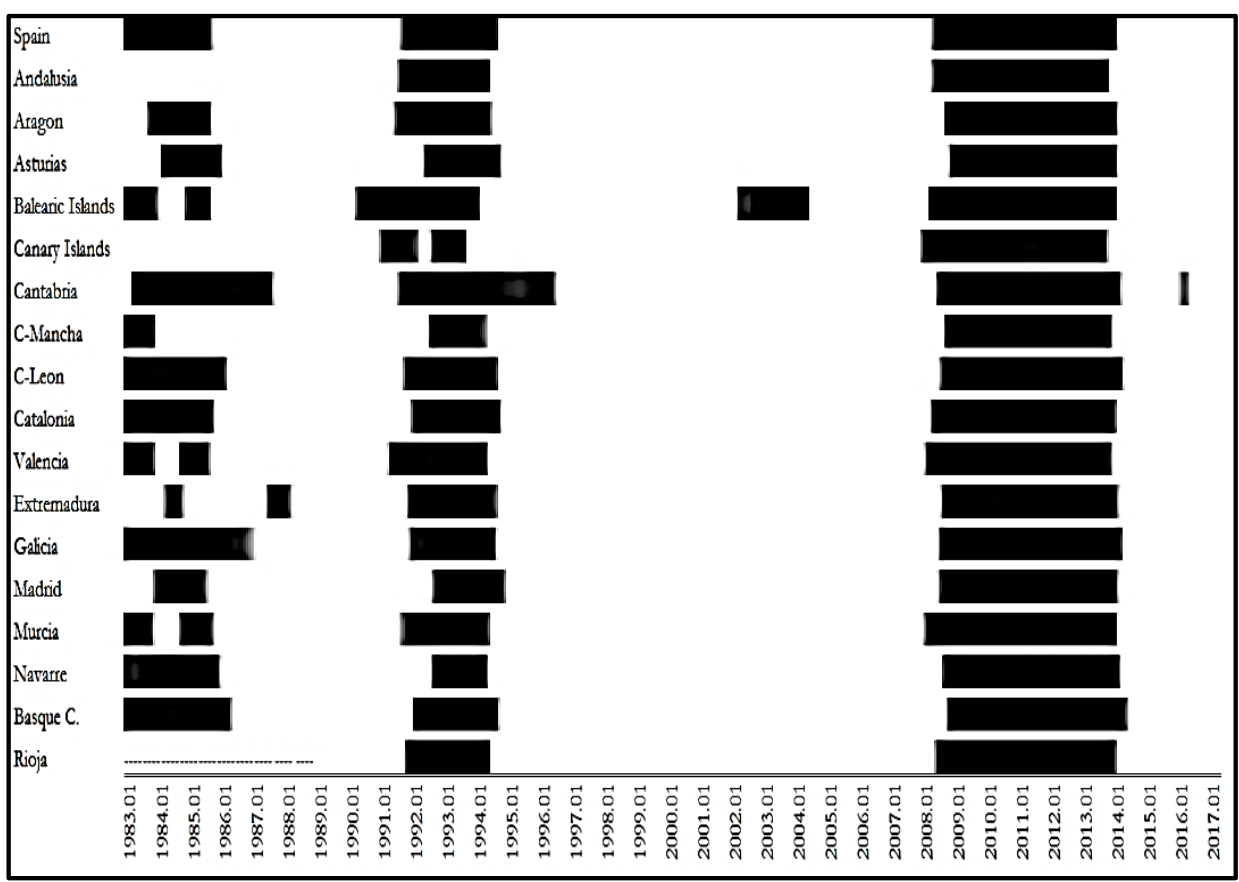

Notes: The figure indicates with shaded areas when a region was in recession in any month: the darker the shade, the stronger the probability that the region was in recession at that time.

Source: Own elaboration base on MEySS data.

In particular, the sample period provides a rich variety of business cycle dynamics. First, while the aggregate economy was facing the 1983-1985 recession, Andalusia, the Canary Islands and Extremadura were undergoing an expansionary phase. Aragon, Asturias and Madrid switched into recession about one year after the national economy did. Moreover, this national recession lasts longer for Cantabria and Galicia, which did not bottom out from their regional downturns until 1987. Finally, the downturn is split into a double-dip recession in the Balearic Islands and Murcia.

Second, Asturias, Castilla-Mancha, Madrid and Navarre entered the national 1991-1994 recession about one year later, while the Balearic Islands were ahead of the national turning point by about one year. The Canary Islands were the first region to leave this recession in 1993. As in the eighties, Cantabria was the last one to switch into expansion, doing so in 1996.

Third, the Balearic Islands experienced a unique idiosyncratic recession in 2002-2004, which is the only discordant note in the 1995-2007 expansion period. The idiosyncratic behaviour of this regional recession might have been 
due to the weakness of international tourism coming into the new century due to the economic slowdown suffered by most European countries at that time.

Fourth, the degree of regional correlation in business cycles since 2008 is unprecedented in the sample. In the last period, all the regional-level business cycle experiences are similar to those of the nation. In particular, every region was experiencing problems at about the same time in 2008-2014, although the Canary Islands, Valencia and Murcia exhibited a certain degree of leading behaviour.

To measure the degree of synchronization of national and regional cycles, we compute the concordance index espoused by Harding and Pagan (2006). The index measures the fraction of time that each of the regional cycles and the national cycle are in the same phase. If we call $s_{t}$ and $s_{k t}$ the unobservable state variables for the nation and the region $k$, the index is defined as

$$
C_{k}=\frac{1}{T}\left(\sum_{t=1}^{T}\left(s_{k t}-s_{t}\right)+\sum_{t=1}^{T}\left(1-s_{k t}\right)\left(1-s_{t}\right)\right),
$$

where $T$ is the total number of periods. The indices, whose estimates are reported in Table 4, have a maximum value of unity when the regional cycle is perfectly synchronized with the national cycle, while it attains a minimum value of zero when both cycles are de-synchronized.

Table 4

Concordance between regional and national business cycles

\begin{tabular}{lcc}
\hline $\begin{array}{c}\text { Autonomous } \\
\text { Communities }\end{array}$ & Concordance & $\begin{array}{c}\text { Null Expected } \\
\text { Concordance }\end{array}$ \\
\hline Andalusia & 0.896 & 0.577 \\
Aragon & 0.950 & 0.558 \\
Asturias & 0.916 & 0.564 \\
Balearic Islands & 0.843 & 0.526 \\
Canary Islands & 0.843 & 0.578 \\
Cantabria & 0.867 & 0.513 \\
C-Mancha & 0.893 & 0.580 \\
C - Leon & 0.968 & 0.545 \\
Catalonia & 0.977 & 0.549 \\
Valencia & 0.942 & 0.554 \\
Extremadura & 0.891 & 0.563 \\
Galicia & 0.941 & 0.540 \\
Madrid & 0.923 & 0.565 \\
Murcia & 0.951 & 0.555 \\
Navarre & 0.939 & 0.560 \\
Basque C. & 0.947 & 0.547 \\
Rioja & 0.975 & 0.562 \\
\hline
\end{tabular}

Notes. The table shows the concordance index espoused by Harding and Pagan (2006).

Source: Own elaboration base on MEySS data. 
These concordance measures should be interpreted relative to an expected value for the concordance between region $k$ and the nation under the null hypothesis that the business cycles of region $k$ and Spain are uncorrelated. ${ }^{11}$ Table 4 also reports these expected concordance measures.

The reported values of the index in Table 4 are large compared to the expected value of the index in the case of uncorrelated cycles. This result suggests that the regions and the nation spend much of the time in the same state of the business cycle. In particular, Catalonia, Castilla-Leon, and La Rioja were in synchronization with the national cycle more than $97 \%$ of the time. In contrast, the Balearic Islands, the Canary Islands, Castilla-Mancha and Extremadura were the regions least synchronised with the national economy.

\section{THE GEOGRAPHY OF NATIONAL RECESSIONS}

So far, we have examined the extent to which the Spanish regions are synchronized with the national business cycle, focusing especially on the periods around the national turning points. In this section, we focus on the geographic perspective in the relationship between state and national recessions. For this purpose, Figures 2 to 4 plot the geographical distribution of regionlevel recessions for certain representative months around the turning points that determine each of the three periods of national recessions.

For each selected month, the figures plot heat (choropleth) maps of the Spanish Autonomous Communities. Each of these maps makes it easy to visualise how the probabilities of recession vary across regions and it shows the level of cross-sectional variability in going into national recessions and facing the subsequent recoveries. For this purpose, each of the regions in the map is shaded in proportion to the regional probability of recession at that time. A dark shade represents a high probability of recession in the region and a light shade represents a low probability.

\subsection{The 1983-1985 national recession}

According to the estimated smoothed recession probabilities for Spain, the first recession in the sample occurs between 1983.01 and $1985.10 .{ }^{12}$ In line with Cancelo (2004), we find that this period was characterized by having the highest heterogeneity in the regional cycles. In fact, Figure 2 shows that in this period we failed to find a month where every region was in expansion in that month.

\footnotetext{
${ }^{11}$ Note that the expected value needs not be 0 if one business cycle phase is more persistent than the other.

${ }^{12}$ We consider a period to be a recession period when for at least two consecutive months in the employment recession probabilities are above 0.5.
} 
Therefore, for all months in this national recession, some states were in recession and others were not.

Figure 2

National recession 1983.01-1985.10 $0^{13}$

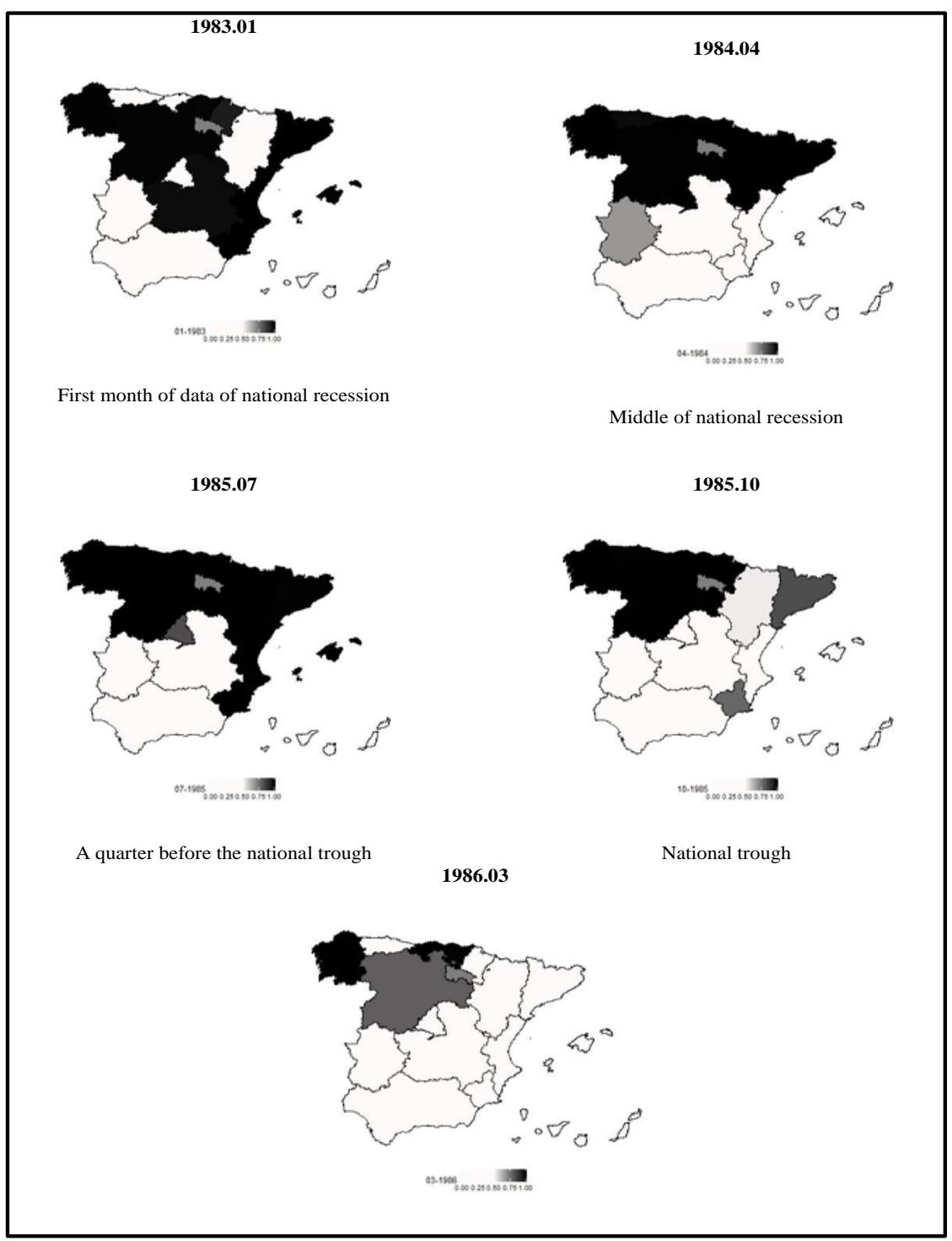

Notes. Two quarters after the national trough.

Source: Own elaboration base on MEySS data.

${ }^{13}$ Data on La Rioja was not available during this recession period 
The first map in Figure 2 plots the geographical business cycle situation at the national peak. The map reveals that most of the northern and Mediterranean regions exhibited a high concordance with the national business cycle in this period and turned into recession. The second map in this figure shows that one year after the national recession began, nearly the entire North was in recession

The third map in Figure 1 shows that one quarter before the national trough, the North and the Mediterranean are the only regions that remain in regional recession. The last two maps in this figure show that, even after the recession had ended at the national level, at the state level it had receded to the Northwest, where it lasted for several more months.

\subsection{The 1991-1994 national recession}

The national recession that began in 1991.09 began in three regions about two quarters before that: The Balearic and Canary islands and Valencia, as the first map of Figure 3 shows. The second map in this figure highlights that regional propagation of this recession goes inward from the periphery to the centre, which did not switch into recession until ten months after Spain did.

The third map in this figure reveals that, by the midpoint of the national recession in 1992.10, all states had entered recession. This geographically widespread recession lasted until 1993.09, which implies a perfect synchronization period that covers $30 \%$ of the national employment recession period.

As the fourth map of Figure 3 shows, the Balearic and Canary islands, and Valencia are again, together with the centre of the country, the regions that led the national trough. As in the recession of the eighties, the Northwest and Catalonia regions were still in regional recession by the time of the national trough.

\subsection{The 2008-2014 national recession}

The latest of the national recessions, which began in 2008.05, was even more geographically widespread than the recession of the nineties. According to the first map in Figure 4, the first signs that a national recession was about to start again came from Valencia and the Canary Islands, although Murcia joined this group of leading regions at this time. The second map in this figure reveals that, once more, the propagation of the recession was from the periphery into the centre.

The third map in the figure shows that for 59 out of the 71 months of national recession ( $80 \%$ of the period), all the regions were also in recession at regional level. Finally, the last two maps in the figure show that the recovery started in the South and was propagated to the North. Again, only north-western 
regions were still in a regional recession by the time the national recession had ended.

Figure 3

National recession 1991.09-1994.09

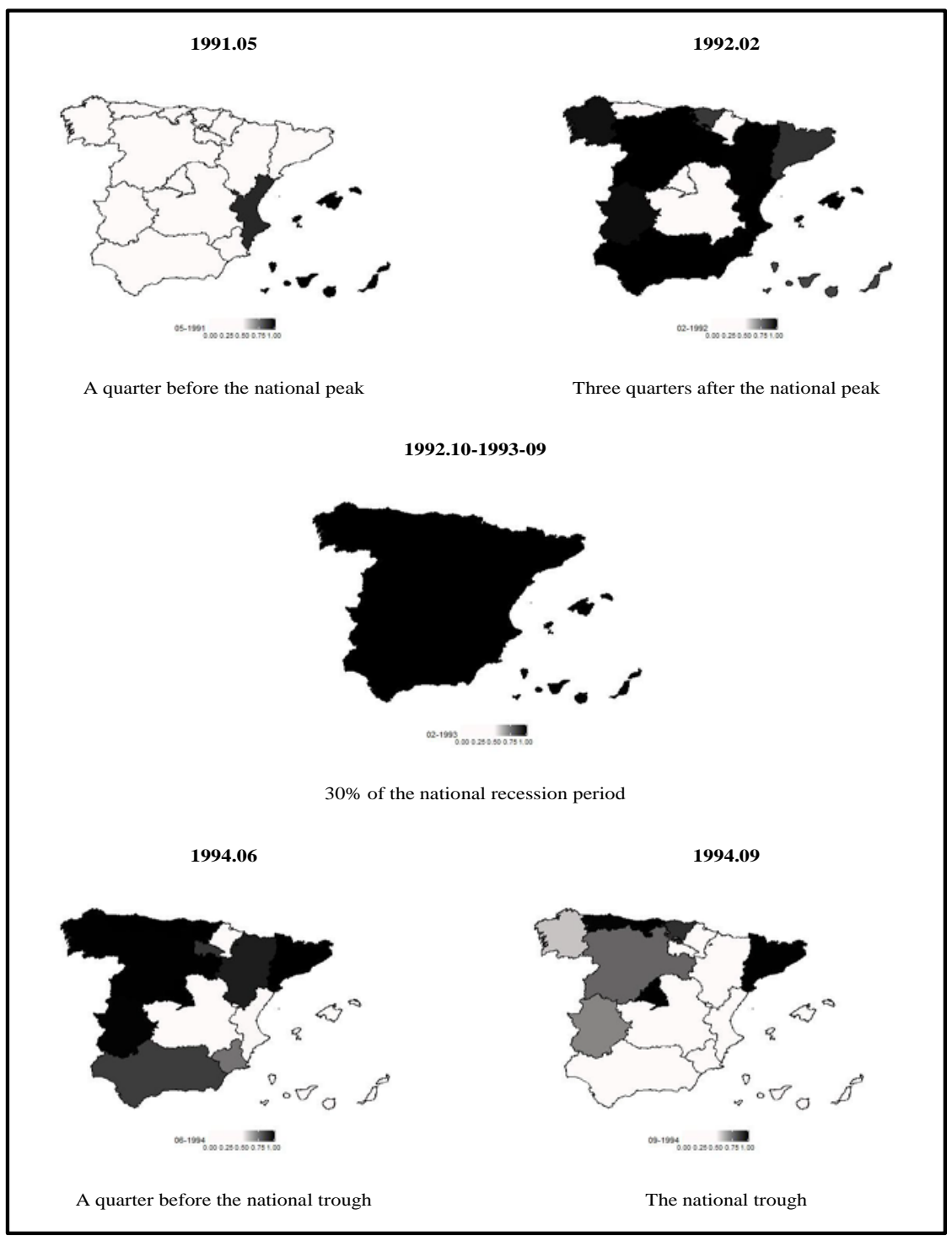

Source: Own elaboration base on MEySS data. 
Figure 4

National recession 2008.05-2014.03

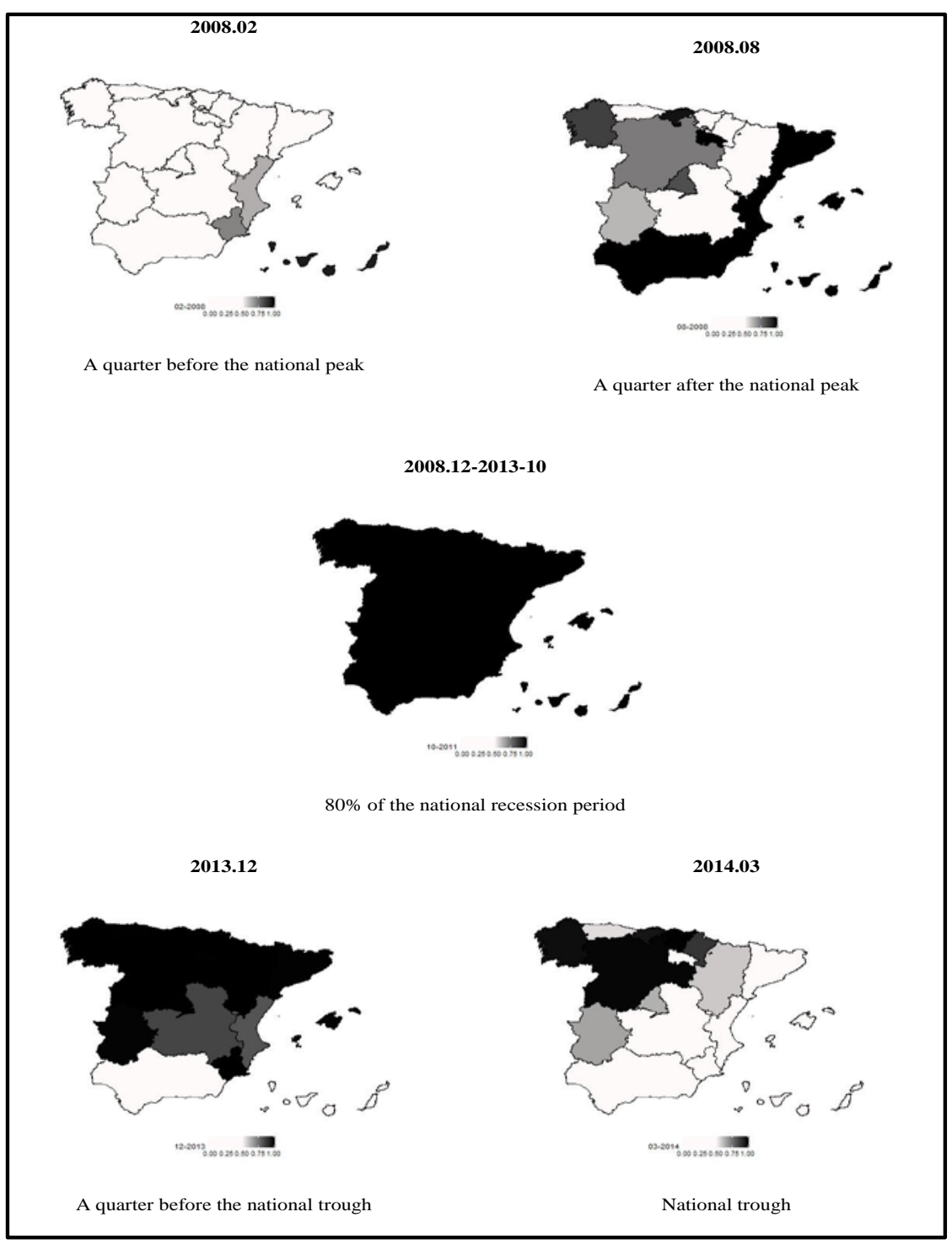

Source: Own elaboration base on MEySS data.

\section{CONCLUSIONS}

In this paper, we estimate a single-equation Markov-switching model for Spain as a whole and for its 17 regions by using total security system affiliation as the measure of economic activity. With respect to other measures of regional 
economic activity, security system affiliation has the advantage of being monthly and early available, which facilitates the analysis of the business cycle.

Using Markov-switching autoregressive models, we find useful evidence about the Spanish regional economic patterns during recession and expansionary periods. Although economic upturns are associated with periods of expansion or periods of positive growth in affiliation levels, and economic downturns refer to recessions or periods in which affiliation drops off, we find that there are large cross-regional differences. The destruction of employment in recession is particularly high in Castilla-La Mancha and Asturias, which also presents the lowest job-creation capacity in expansionary phases. However, Mediterranean regions tend to amplify the business cycle in terms of employment and Madrid, Navarre and Cantabria show within-regime growth rates in affiliation that closely match those nationwide.

Our results suggest that there is a high degree of regional business cycle synchronization, which has notably increased during the sample period. We nonetheless find significant differences across regions in growth rates within business cycle phases, as well as regarding the dates of their turning points. First, the Canary Islands, Valencia, and to a lesser extent the Balearic Islands, seem to be the leading regions when going into recession, while the central regions of the country present lagging. Second, the regional transmission of recession to the national level seems to be from the periphery into the centre. Finally, north-western regions take longer than the nation to pull out of their recessions.

We consider that our results have potentially important implications for national and regional policy-making. The common view of a country's business cycle as the aggregation of the regional cycles obscure the timing in which the different regions fall into a recession and experience the recoveries. If some regional cycles are systematically asynchronous, inflexible fiscal stability across regions could constrain future stability oriented public expenditures devoted to smooth cyclical swings of regional economic activity.

Notably, the models are estimated separately, which implies an ex ante agnostic approach regarding the dependency of business cycle phases across regions. Although this simplifies analysis of Spanish regional business cycles, it precludes us from examining the facet in the data where knowing whether one region is in recession at a given date could be helpful for predicting whether another state will be on the following date. We have left this interesting additional angle for further research. 


\section{BIBLIOGRAPHY REFERENCES}

ANDRÉS, J., and DOMÉNECH, R. (2015). En busca de la prosperidad: Los retos de la sociedad española en la economía global del s. XXI. Deusto.

ALVAREZ, R., CAMACHO, M., and RUIZ, M. (2018). "Inference on filtered and smoothed probabilities in Markov-switching autoregressive models". Journal of Business and Economic Statistics. Forthcoming.

BANDRES, E., GADEA-RIVAS, M., and GOMEZ-LOSCOS, A. (2017). "Regional business cycles across Europe". Bank of Spain Working Paper 1702.

BASILE, R., and GIRARDI, A. (2018). "Uncertainty and business cycle: A review of the literature and some evidence from the Spanish economy". Estudios de Economía Aplicada 36-1, pp. 235-250.

BLANCHARD, O., QUAH, D. (1989). "The dynamic effects of aggregate demand and supply disturbances". The American Economic Review, 79(4), pp. 655-673.

BRY, G., and BOSCHAN, C. (1971). "Cyclical analysis of time series: selected procedures and computer programs". NBER, New York.

CAMACHO M, and PEREZ-QUIROS, G. (2007). "Jump-and-rest effect of U.S. business cycles". Studies in Nonlinear Dynamics and Econometrics, 11(4), article 3.

CANCELO J. (2004). "El ciclo del empleo en España. Un análisis regional". Revista económica de Castilla La Mancha, 4, pp. 107-138.

CHAUVET, M., and HAMILTON, J. (2006). "Dating business cycle turning points in real time". In Nonlinear Time Series Analysis of Business Cycles, eds. C. Milas, P. Rothman, and D. Van Dijk. Amsterdam: Elsevier Science, pp. 1-54.

DIXON, R. J., LIM, G. C. and VAN OURS, J. C. (2016). "Revisiting Okun's relationship". CEPR Discussion Paper No. DP11184.

GADEA, M., GOMEZ-LOSCOS, A., and MONTAÑES, A. (2012). "Cycles inside cycles: Spanish regional aggregation". SERIEs 3, pp. 423-456.

GALÍ, J. (1999). "Technology, employment, and the business cycle: Do technology shocks explain aggregate fluctuations?" The American Economic Review, 89, pp. 249-271.

KYDLAND, F., and PRESCOTT, E. (1982). "Time to build aggregate fluctuations". Econometrica, 50, pp. 1345-1370.

HAMILTON J. (1989). "A new approach to the economic analysis of nonstationary time series and the business cycles". Econometrica, 57, pp. 357-384.

HAMILTON, J., and OWYANG, M. (2012). "The propagation of regional recessions". The Review of Economics and Statistics, 94, pp. 935-947.

HARDING, D., and PAGAN, A. (2006). "Synchronization of cycles". Journal of Econometrics, 132, pp. 59-79.

LEIVA-LEON, D., GADEA-RIVAS, M., and GOMEZ-LOSCOS, A. (2017). "The evolution of regional economic interlinkages in Eurpe". Bank of Spain Working Paper 1708.

OWYANG, M., PIGER, J., and WALL, H. (2005). "Business cycle phases in the U.S. states". The Review of Economics and Statistics 87, pp. 604-616.

OWYANG, M., PIGER, J., WALL, H., and WHEELER, C. (2008). "The economic performance of cities: A Markov-switching approach". Journal of Urban Economics, 64, pp. 538-550. 
OZYURT, S., and DEES, S. (2015). "Regional dynamics of economic performance in the EU: To what extent do spatial spillovers matter?" European Central Bank Working Paper 1870. 


\section{Appendix}

Figure A1

Probability of recession

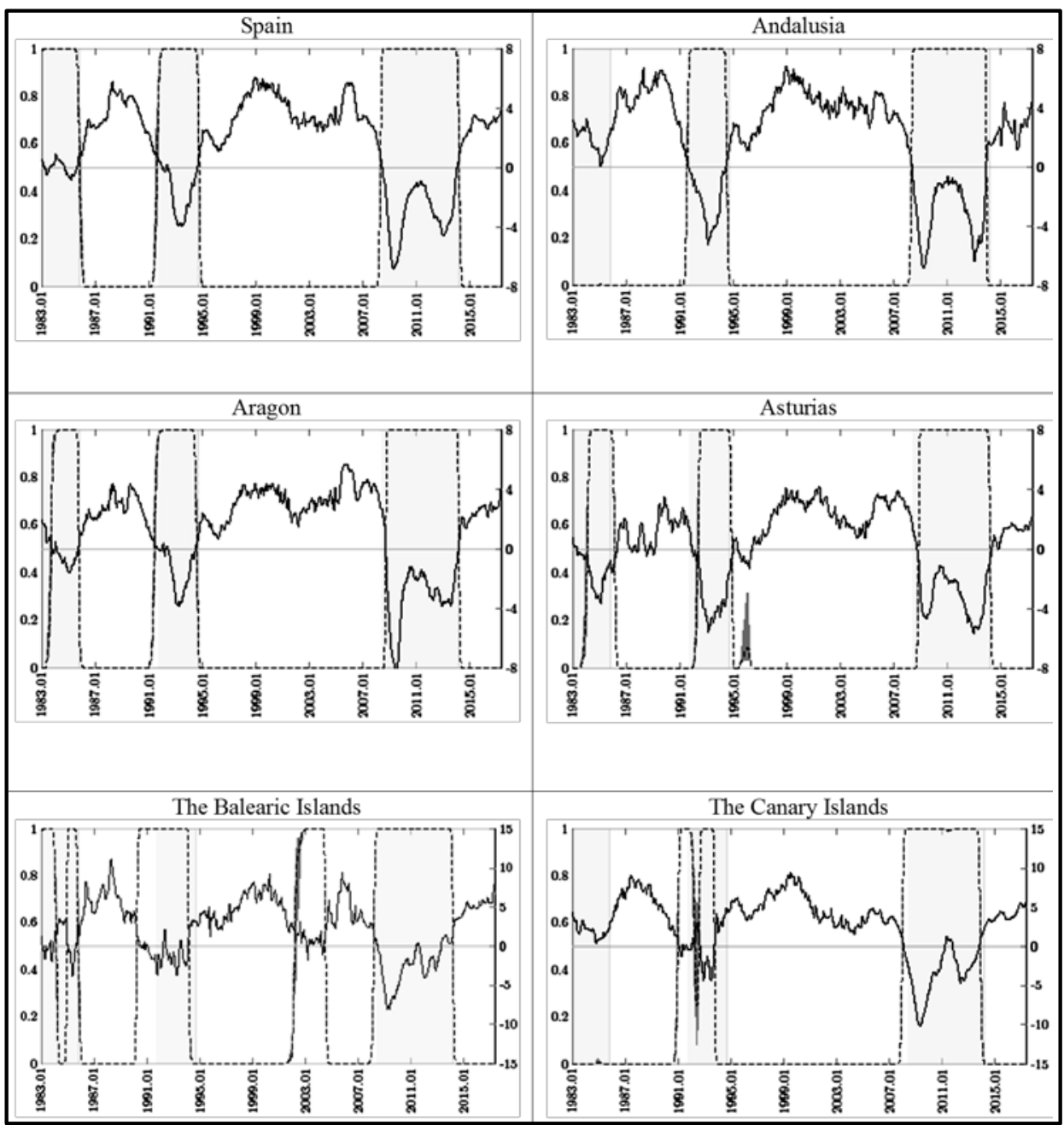

Notes: The blue line shows Social Security affiliation levels (right axis) for Spain and Spanish autonomous communities. In dashed red line it is shown the probability of recession with its $95 \%$ confidence intervals (left axis). The grey shadow areas correspond to aggregate employment recession in Spain.

Source: Own elaboration base on MEySS data. 
Figure A1

Probability of recession (continued)

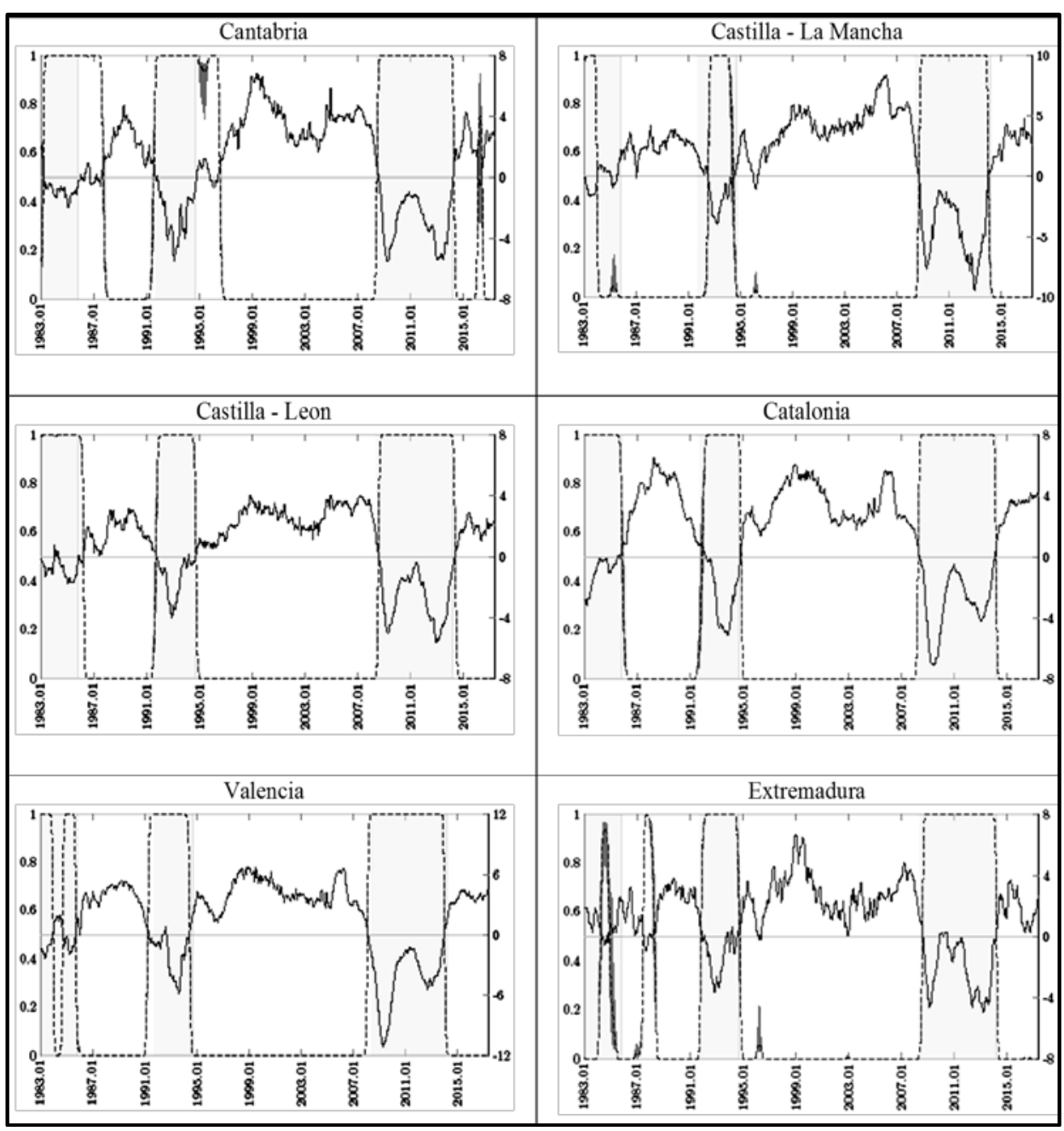

Notes: The blue line shows Social Security affiliation levels (right axis) for Spain and Spanish autonomous communities. In dashed red line it is shown the probability of recession with its $95 \%$ confidence intervals (left axis). The grey shadow areas correspond to aggregate employment recession in Spain.

Source: Own elaboration base on MEySS data. 
Figure A1

Probability of recession (continued)

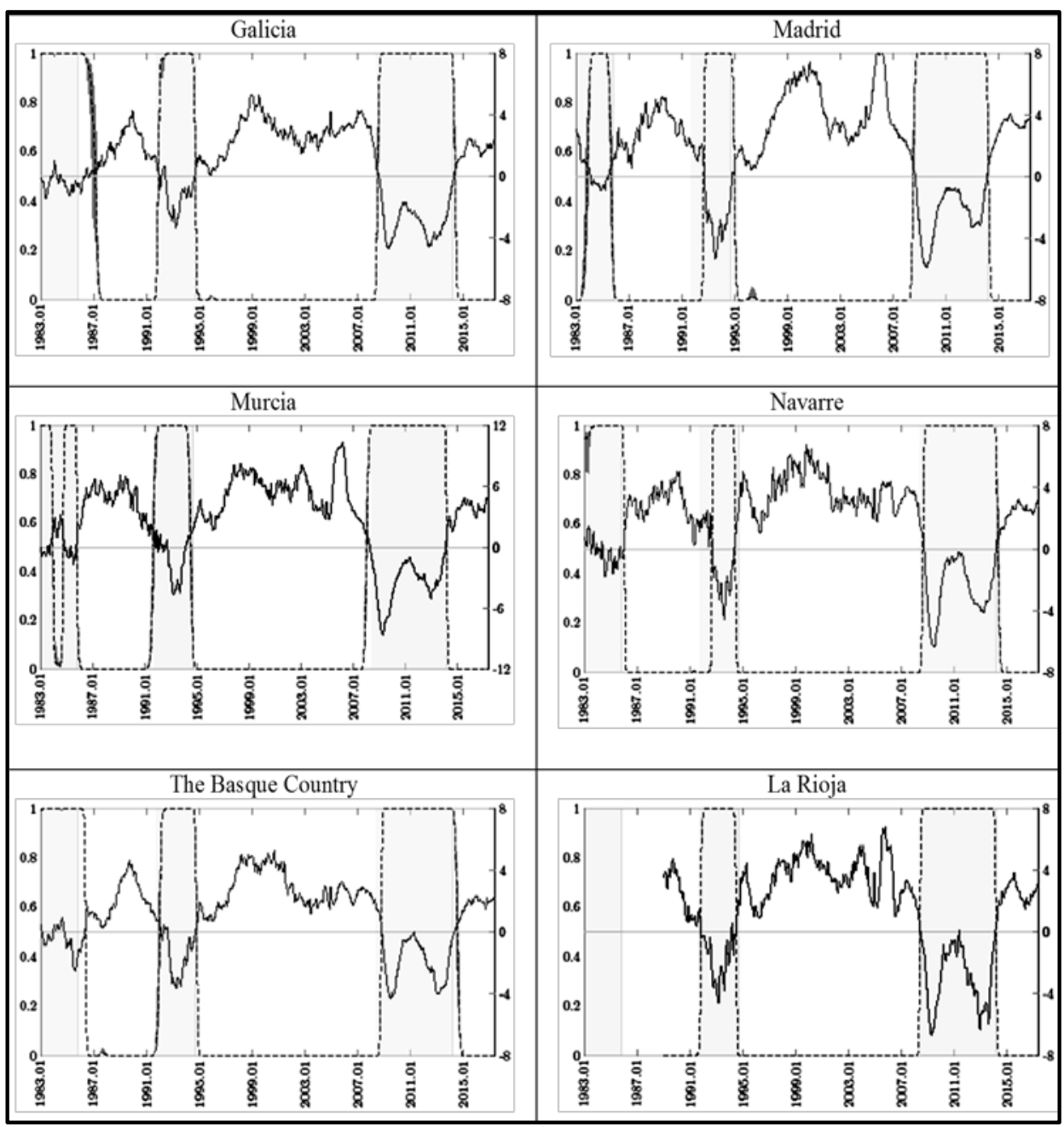

Notes: The blue line shows Social Security affiliation levels (right axis) for Spain and Spanish autonomous communities. In dashed red line it is shown the probability of recession with its 95\% confidence intervals (left axis). The grey shadow areas correspond to aggregate employment recession in Spain.

Source: Own elaboration base on MEySS data. 